\title{
Impact of space and rocket activity on soil cover in central Kazakhstan
}

\author{
Murat Toktar ${ }^{2, *}$, Zhaylaubay Zhubato ${ }^{1}$, Yelena Stepanova $^{1}$, Erlan Bekeshev ${ }^{1}$ \\ ${ }^{1}$ Republican State Enterprise «Scientific Research Centre «Garysh-Ecology» (RSE «SRC «Garysh- \\ Ecology») of the Aerospace Committee of the Ministry of Defense and Aerospace Industry of the \\ Republic of Kazakhstan, Almaty, Kazakhstan \\ ${ }^{2}$ M. Kozybaeve North Kazakhstan state university, Pushkin 86, Postcode: 150000
}

\begin{abstract}
The results of environmental monitoring and integrated assessment of the stability of brown, mostly solonetzic soils and solonchaks to chemical pollution and mechanical stresses at the fall places of the first stage of "Proton" launch vehicle (LV) in the Yu-2 zone (Central Kazakhstan) are provided. With the help of GIS technologies, zoning maps of the investigated territory have been created based on the criteria of soil cover resistance to the impact of space and rocket activity (SRA).
\end{abstract}

\section{Introduction}

The areas of the territory of the Republic of Kazakhstan are currently occupied by the an impact areas of separating parts of space launch vehicles (SLV SP IA). These fields, which are located in sparsely populated regions of the country, have been actively exploited by the Baikonur Cosmodrome as a crash site of depleted parts of missile that dispose the Spacecraft into orbit around Earth and geostationary orbit. The complete or partial destruction of the SLV SP (first and second stages, heat shield, and etc.) during the fall and its impact on the ground is often accompanied by mechanical disturbance of the soil and vegetation fire, pollution of the environment with debris and remnants of toxic propellant components that have not burnt in dense layers of atmosphere [1]. Thus, unsymmetric dimethylhydrazine (UDMN) being used in the «Proton» LV as a rocket fuel acts as a base and an active reducing agent by its chemical properties, it is easily oxidized by various oxidants and reacts with compounds that contain a carbonyl group. UDMN belongs to the group of carcinogenic and mutagenic substances of the first class of the risk of human exposure. Therefore, monitoring surveys of the state of the soil cover in SLV SP IA is a very topical issue [2-5].

During the period of intensive exploitation by the Baikonur Cosmodrome (1989-2010), 27 falls of the first stages of the «Proton» LV were registered in the territory of the Yu-2 zone with an area of 0.1 million hectares. On the fields of Kazakhstan's territory, subject to long-term exposure to the SRA as a SLV SP IA, the soil takes the main share of the technogenic load in the form of mechanical and pyrogenic deformation of soil horizons,

* Corresponding author: murat-toktar@mail.ru 
disturbance of balanced development of soil biocenosis [6-7]. Taking into account the risk of negative consequences for the environment, the implementation of the SRA in the Yu-2 zone remains a potential factor of external technical impact on the ecosystem, despite that 7 years have passed since the last fall of the first stage of the «Proton» LV. This aspect provides the basis for monitoring of the natural ecosystem in the $\mathrm{Yu}-2$ zone with subsequent assessment of its environmental sustainability.

For the studies regularly carried out in the Kazakhstani SLV SP IA, the criteria of environmental sustainability are used, which reflect factors that can disturb the equilibrium state of natural ecosystems as abiotic (weather and climate conditions, terrain topography, morphogenetic and physicochemical properties of land cover, etc.) and anthropogenic (SRA, household activities, grazing on pastures, and etc.). The key subject of environmental assessment are biocenosis, since environmental sustainability can be explained only on the basis of biotic compensation of all fluctuations and directed abiogenic changes [8].

\section{Materials and Methods}

The Yu-2 zone is located in the semi-desert landscape zone (Central Kazakhstan), where the processes of self-cleaning of ecosystem from chemical contamination by the rocket fuel components (RFC) are largely conditioned by sharply continental climate with increased thermal resources and a low amount of atmospheric precipitation, and frequent thunderstorms, which leads to an accelerated oxidation by the products of technogenesis and their rainout (up to 11-14 days with a thunderstorm in June). Aerogenic transport of pollutant transformation products in the $\mathrm{Yu}-2$ zone becomes possible with wind strengthening, especially accompanied by dust storms and snow blizzards (8-20 days with snowstorms per year). The maximum daily air temperature amplitudes are observed in the warm period of the year with a clear sky $\left(16.1^{\circ} \mathrm{C}\right)$; minimum - in the winter with a cloudy sky $\left(5.3^{\circ} \mathrm{C}\right)$. The average duration of the frost-free period is $110-160$ days, the period of stable snow cover is 105-160 days, the annual precipitation is about $200 \mathrm{~mm}$. Rainfall prevails over snow. The greatest amount of precipitation falls in the warm period (80-120 $\mathrm{mm}$ ), in the cold period - 70-75 $\mathrm{mm}$. In the territory of the Yu-2 zone, north-eastern and northern winds predominate at a speed of $4.0-4.5 \mathrm{~m} / \mathrm{s}$ (at an average annual rate).

There can be observed the benefits of the processes of physicochemical and biological decomposition and migration of UDMN in the descending stream of soil moisture or with meltwater in the land cover of the Yu-2 zone (brown soils, solontzic) with low humus content and alkaline reaction of the $\mathrm{pH}$ range. The time frame for these processes is limited due to the aridity of the spring-summer period.

In June 2017, monitoring environmental studies were carried out at 34 locations of the SLV SP IA in the Yu-2 zone and at a control point on the contiguous territory (map in Figure 1), with selection of 240 soil samples for quantitative chemical analysis (QCA) for content of rocket fuel components (RFC), including usymmetric dimethylhydrazine (UDMN) and the product of its chemical transformation, nitrosodimethylamine (NDMA). The following QCA methods are used: determination of UDMN by ion chromatography with amperometric detection (MVI No. 41-01; KZ.07.00.01779-2013); determination of NDMA by reversed-phase liquid chromatography with spectrophotometric detection (MVI No. 103-08 KZ.07.00.03190-2015); determination of nitrate ions by ionometry (GOST 26951-86). Soil profiles were described according to standard soil survey methods [9]. From each soil horizon, representative samples were collected. Bulk soil samples were air dried, gently crushed and passed through a 2-mm sieve and analysis undertaken using fine earth. Soil texture was analysed using the pipette method following dispersion after 3-h shaking with $0.1 \mathrm{M} \mathrm{Na}_{4} \mathrm{P}_{2} \mathrm{O}_{7}$ [10-11]. Total carbonates were determined by gas-volumetric 
method. Soil $\mathrm{pH}$ was measured po-tentiometrically in 1:2.5 w/v suspension (soil:1M KCl and soil: $\mathrm{H}_{2} \mathrm{O}$ ), using a Metrohm 691 with a glass electrode AC 9101. Total $\mathrm{N}$ was determined by Kjeld-hal's method. The analysis of organic carbon was performed using the Walkley-Black Wet Oxidation method and organic matter was calculated from Corg (i.e. Corg x 1.724). Total potassium was determined according to Radov et al [14]. $\mathrm{P}_{2} \mathrm{O}_{5}$ tot was carried out following the Russian Handbook on the Chemical Analysis of Soils [15].

\section{Results and discussion}

Analysis of the dynamics of RFC pollution in soils at the fall places of the first stage of "Proton" LV in the Yu-2 zone

For 5 years of observations (during the period of 2002-2007) in brown solonetz of KU-2 (the place of fall from 30.12.1998), concentration of UDMN has decreased more than 20 times - from $13.83 \mathrm{mg} / \mathrm{kg}$ (multiplicity of maximum threshold limit value of UDMN is 138 $\mathrm{TLV}=0.1 \mathrm{mg} / \mathrm{kg}$ ) to $0.65 \mathrm{mg} / \mathrm{kg}(6.5 \mathrm{TLVs})$. In brown soils of MP-5 (the place of fall from 04.04.1991), the content of UDMN has decreased by 4.5 times - from $0.55 \mathrm{mg} / \mathrm{kg}(5.5$ TLVs) to $0.12 \mathrm{mg} / \mathrm{kg}$ (1.2 TLVs). In brown solonetzic soils of KU-3 (place of fall from 05.09.2000), UDMN was detected only in 2002, in an amount of $110.4 \mathrm{mg} / \mathrm{kg}(1,104 \mathrm{TLVs})$. 


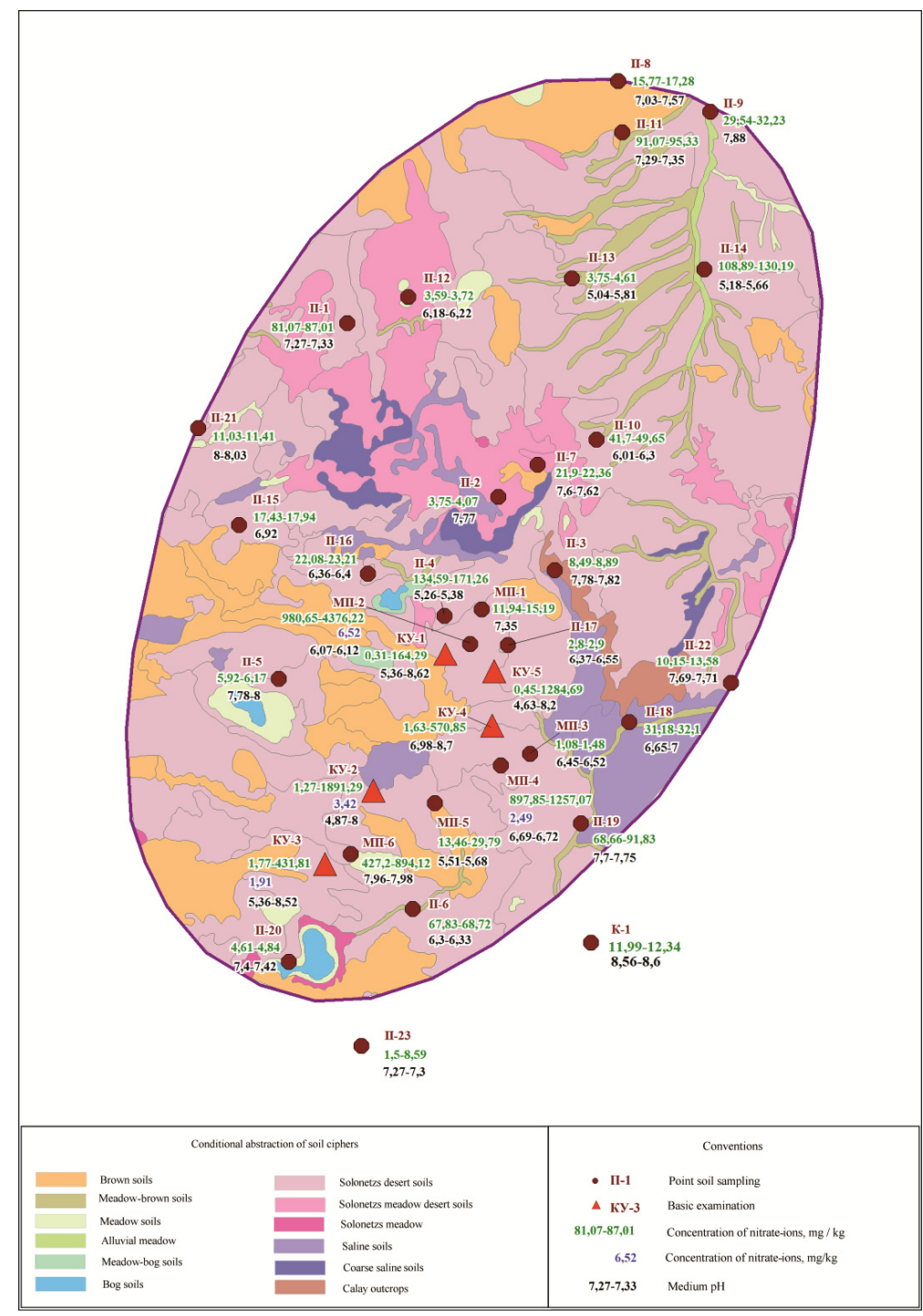

Fig.1 - Map-scheme of zoning according to the criteria of chemical contamination of soils in the $\mathrm{Yu}-2$ zone in June 2017

Analysis of the dynamics of RFC pollution in soils at the fall places of the first stage of "Proton" LV in the Yu-2 zone

Place of fall from 30.12.1998), UDMN concentration has decreased more than 20 times - from $13.83 \mathrm{mg} / \mathrm{kg}$ (multiplicity of maximum threshold limit value of UDMN is 138 $\mathrm{TLV}=0.1 \mathrm{mg} / \mathrm{kg}$ ) to $0.65 \mathrm{mg} / \mathrm{kg}(6.5 \mathrm{TLVs})$. In brown soils of MP-5 (the place of fall from 04.04.1991), the content of UDMN has decreased by 4.5 times - from $0.55 \mathrm{mg} / \mathrm{kg}(5.5$ TLVs) to $0.12 \mathrm{mg} / \mathrm{kg}$ (1.2 TLVs). In brown solonetzic soils of KU-3 (place of fall from 05.09.2000), UDMN was detected only in 2002, in an amount of $110.4 \mathrm{mg} / \mathrm{kg}$ (1,104 TLVs).

In the years of further observations in the Yu-2 zone $(2011,2017)$, the UDMN was no longer detected in the soils of the fall places of SLV SP. So, in 2017, UDMN and NDMA were not found in all 240 soil samples under study within the sensitivity range of applied 
QCA techniques $(<0.05 \mathrm{mg} / \mathrm{kg}$ of UDMN, $<0.05 \mathrm{mg} / \mathrm{kg}$ of NDMA).

In the period of 2007-2017 years, at the fall places of «Proton» LV in the Yu-2 zone the 11-fold increase in nitrate ion concentrations in brown solonetz KU-2 (1.3-14.6 TLV nitrate ions $=130 \mathrm{mg} / \mathrm{kg}$ ) and 2-fold in brown solonetzic soils KU-3 (1.5-3.3 TLVs) was observed. On the contrary, in the brown soils of MP-5, the amount of nitrate ion decreased by 12.8 times - from 2.9 TLVs in 2007 to $0.2 \mathrm{TLV}$ in 2017.

In 2017, in the Yu-2 zone nitrate ion was detected in all studied 240 soil samples, an average of $98.8 \mathrm{mg} / \mathrm{kg}$ (Table 1). The excess of the TLV of the nitrate ion in the soil was found mainly in the epicenters of the old fall places of SLV SP from 1980 to 2000 years (center and south of Yu-2). In the topsoil of 0-25 $\mathrm{cm} \mathrm{3.3-33.7} \mathrm{TLVs} \mathrm{were} \mathrm{detected,} \mathrm{in} \mathrm{the}$ underlying layer of 25-50 cm several times less - 1.2-7.5 TLVs. At separate points on desert solonetz, elevated concentrations of nitrate ion were also found at depths in the $75-100 \mathrm{~cm}$ layer (1.1-3.9 TLVs).

Table 1 - Nitrate ions in the soils of the Yu-2 zone in June 2017

\begin{tabular}{|c|c|c|c|}
\hline \multirow[t]{2}{*}{ Name of the trial plot } & \multicolumn{3}{|c|}{$\begin{array}{c}\text { Limits of nitrate content, } \mathrm{mg} / \mathrm{kg} \\
\text { Threshold limit value of nitrates in soil }=130\end{array}$} \\
\hline & $\min$ & $\max$ & mean \\
\hline \multicolumn{4}{|c|}{ Locations of a local survey of places where the LV «Proton» first steps fell } \\
\hline MP-1, LV start-up date unknown & 11,9 & 15,2 & 13,6 \\
\hline MP-2, LV start-up date unknown & $\begin{array}{l}980,7(7,5 \\
\text { TLVs) }\end{array}$ & $4376,2(33,7$ TLVs $)$ & $2678,4(20,6$ TLVs $)$ \\
\hline $\begin{array}{l}\text { MP-3 LV start-up date } \\
\text { approximately in 1985-87. }\end{array}$ & 1,08 & 1,48 & 1,3 \\
\hline $\begin{array}{l}\text { MP-4, LV start-up date } \\
31.05 .1989 .\end{array}$ & $\begin{array}{c}897,9 \\
(6,9 \mathrm{TLVs}) \\
\end{array}$ & 1257,07 (9,7 TLVs) & $1077,5(8,3$ TLVs $)$ \\
\hline $\begin{array}{l}\text { MP-5, LV start-up date } \\
04.04 .1991 .\end{array}$ & 13,5 & 29,8 & 21,6 \\
\hline $\begin{array}{l}\text { MP-6, LV start-up date } \\
01.07 .2000 .\end{array}$ & $\begin{array}{c}427,2 \\
(3,3 \text { TLVs }) \\
\end{array}$ & $894,1(6,9$ TLVs $)$ & $660,7(5,1 \mathrm{TLVs})$ \\
\hline Mean by MP & 1,08 & 4376,2 (33,7 TLVs) & 472,2 (5,7 TLVs) \\
\hline \multicolumn{4}{|c|}{ Sites of local study of places with detection in the soil of RFC in $2000-2011$} \\
\hline $\begin{array}{l}\text { KU-1, LV start-up date } \\
\text { approximately in } 1995 .\end{array}$ & 0,31 & $164,0(1,3 \mathrm{TLV})$ & 50,3 \\
\hline $\begin{array}{l}\text { KU-2, LV start-up date } \\
\text { 30.12.1998. }\end{array}$ & 1,27 & $1891,3(14,6 \mathrm{TLVs})$ & 107,2 \\
\hline $\begin{array}{l}\text { KU-3, date of start-up of the LV } \\
05.09 .2000 \text {. }\end{array}$ & 1,8 & 431,8 & 43,97 \\
\hline $\begin{array}{l}\text { KU-4, LV start-up date } \\
\text { approximately at the end in } 1980 .\end{array}$ & 1,6 & $570,9(4,4 \mathrm{TLVs})$ & 87,02 \\
\hline KU-5 LV start-up date unknown & 0,45 & $1284,7(9,9 \mathrm{TLVs})$ & 75,1 \\
\hline Mean by KU & 0,31 & $\begin{array}{c}1891,3 \\
(14,6 \text { TLVs })\end{array}$ & 72,7 \\
\hline Mean by P (area survey sites) & 1,5 & $171,3(1,3 \mathrm{TLVs})$ & 36,9 \\
\hline Control point K-1 & 11,99 & 12,34 & 12,2 \\
\hline $\begin{array}{l}\text { Mean in the Yu-2 and contiguous } \\
\text { territory }\end{array}$ & 0,31 & $4376,2(33,7$ TLVs $)$ & 98,8 \\
\hline
\end{tabular}

Analysis of physical, chemical and morphological properties

Brown solonetz, meadow-brown solonetz, meadow and brown solonetz, and solonchak typical, meadow and sodic (soil map-scheme is illustrated in Fig. 1) prevail in the SLV SP fall places of the central and south part of Yu-2 zone. In June 2017, signs of disturbance in 
the soil structure as well as of planar and linear erosion of soils (nano- and micro-r-ills with a depth of 10-25 cm, recesses, funnels with a depth of 0.5-4.0 m diameter of 1.5-7.0 m) were discovered in the SLV SP fall places (photo in Fig. 2).

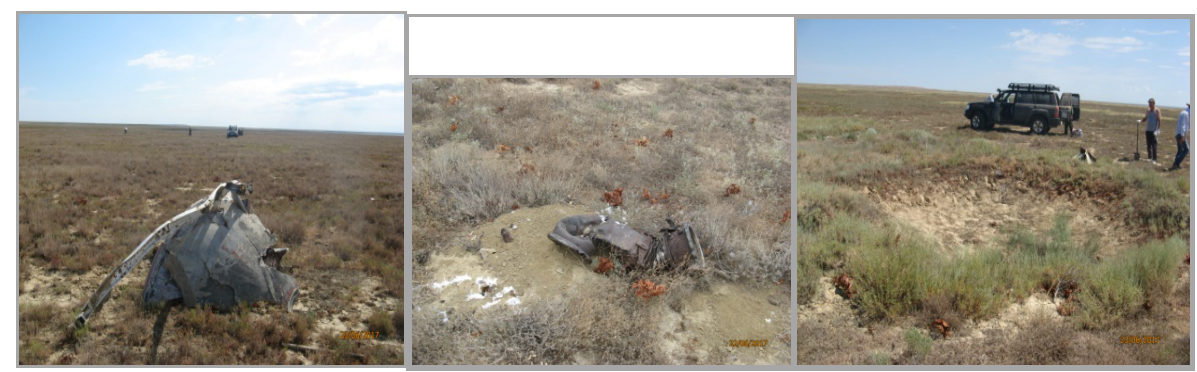

Fig. 2 - The places of falling of the Proton LV first stage in the zone Yu-2 in June 2017.

Tables 2-4 show the main morphological, chemical and physical properties of the soil profiles in the perspective of three insections made in 2017 at the two fall places of the first stage of «Proton» LV in the $\mathrm{Yu}-2$ zone and at control point with conditionally clean soil (Fig. 3):

1 KU-2 at the place of SLV SP falling in 30.12.1998;

2 KU-3 at the place of SLV SP falling in 05.09.2000;

$3 \mathrm{~K}-1$ at the control point on the adjacent territory.

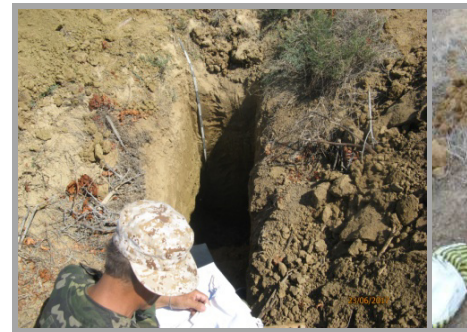

KU-2

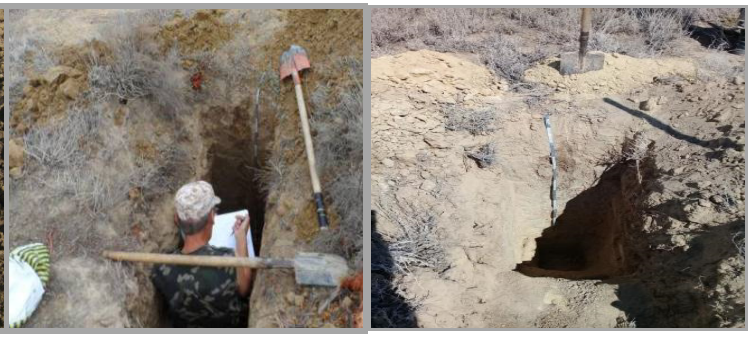

KU-3

K-1

Fig.3 - Soil insections in June 2017 in the Yu-2 zone

According to the results of surveys conducted in 2017 it was determined that the soil profiles at the KU-2 crash sites (small brown solonetzic), KU-3 (brown saline alkali sabulous soils) and at the K-1 control point (brown saline alkali soil solonetzic light loamy soils) are characterized by a small capacity of humus horizons (about $12 \mathrm{~cm}$ ) (Table 2). In the upper horizon A, the color varies from pale-gray, brownish-gray to light-brownish, and in the lower horizon $\mathrm{C}$ to yellowish-brownish. The topsoil horizons (A) are soft; B, C dense, BC - condensed.

Table 2 - Main morpho-descriptive characteristics of the insections surveyed

\begin{tabular}{|c|c|c|c|c|c|c|c|c|}
\hline $\begin{array}{l}\text { M } \\
\text { (Hori } \\
\text { zon) }\end{array}$ & $\begin{array}{l}\text { Depth } \\
(\mathrm{cm})\end{array}$ & $\begin{array}{l}\text { aBo } \\
\text { und } \\
\text { ary }\end{array}$ & $\begin{array}{l}\text { Color } \\
\text { (dry) }\end{array}$ & $\begin{array}{l}\text { bStru } \\
\text { cture }\end{array}$ & cTexture & $\begin{array}{l}\text { dConsist } \\
\text { ence } \\
\text { (dry) }\end{array}$ & $\begin{array}{l}\text { eEfferv } \\
\text { escence }\end{array}$ & $\begin{array}{l}\text { fRoot } \\
\text { s }\end{array}$ \\
\hline \multicolumn{9}{|c|}{$\begin{array}{l}\text { KU-2. The place where the LV «Proton» first steps fell in } 30.12 .1998 \\
\text { Solonetz brown small }\end{array}$} \\
\hline $\mathrm{A}$ & $0-9$ & $\mathrm{C}$ & 10YR5/2 & $\begin{array}{l}\text { SG, } \\
\text { f\&m, } \\
1\end{array}$ & $\mathrm{C}$ & $\mathrm{SO}$ & 2 & $1, \mathrm{f}$ \\
\hline
\end{tabular}




\begin{tabular}{|l|l|l|l|l|l|l|l|l|}
\hline B1 & $9-21$ & C & 10 YR7/1 & $\begin{array}{l}\text { SG\& } \\
\text { SG } \\
\text { f\&m, } \\
1\end{array}$ & CL & SH & 3 & $1, \mathrm{f}$ \\
\hline B2 & $21-32$ & U & 10 YR6/3 & $\begin{array}{l}\text { abk\& } \\
\text { SbC, } \\
\text { f\&m, } \\
2\end{array}$ & CL & H & 3 & $1, \mathrm{f}$ \\
\hline BC & $32-77$ & G & 2.5 Y 7/3 & $\begin{array}{l}\text { SG\& } \\
\text { abk, } \\
\text { f\&m, } \\
2\end{array}$ & L & VH & 3 & $1, \mathrm{vf}$ \\
\hline C1 & $77-99$ & C & 2.5 Y 7/4 & $\begin{array}{l}\text { SG\& } \\
\text { abk, } \\
\text { f\&m, } \\
2\end{array}$ & SL & H & 3 & 0 \\
\hline C2 & $\begin{array}{l}99- \\
196\end{array}$ & U & 2.5 Y 7/6 & MA & SL & H & 3 & 0 \\
\hline
\end{tabular}

KU-3. The place where the LV «Proton» first steps fell in 05.09.2000

Brown solonetsous sandy loam soils

\begin{tabular}{|c|c|c|c|c|c|c|c|c|}
\hline A & $0-12$ & $\bar{C}$ & 10YR6/3 & $\begin{array}{l}\text { SG\& } \\
\text { abk, } \\
\text { f\&m, } \\
1\end{array}$ & SCL & SO & 2 & $1, \mathrm{f}$ \\
\hline B & $12-32$ & $\mathrm{C}$ & 10YR6/6 & $\begin{array}{l}\text { CO\& } \\
\text { SbC, } \\
\text { f\&m, } \\
1\end{array}$ & $\mathrm{~L}$ & $\mathrm{H}$ & 2 & $1, \mathrm{f}$ \\
\hline $\mathrm{BC}$ & $32-55$ & $\mathrm{C}$ & 10YR6/2 & $\begin{array}{l}\text { abk\& } \\
\text { SbC, } \\
\text { f\&m, } \\
1\end{array}$ & SL & VH & 3 & $1, \mathrm{f}$ \\
\hline $\mathrm{C} 1$ & $55-90$ & G & $2.5 \mathrm{Y} 6 / 6$ & $\begin{array}{l}\text { SG\& } \\
\text { abk, } \\
\text { f\&m, } \\
2\end{array}$ & SL & $\mathrm{H}$ & 3 & $1, \mathrm{vf}$ \\
\hline $\mathrm{C} 2$ & $\begin{array}{l}90- \\
185\end{array}$ & U & $2.5 \mathrm{Y} 6 / 6$ & $\begin{array}{l}\text { MA, } \\
\text { f\&m, } \\
2\end{array}$ & L & $\mathrm{H}$ & 3 & 0 \\
\hline \multicolumn{9}{|c|}{$\begin{array}{l}\text { K-1. Control point with conditionally clean soil at contiguous territory } \\
\text { Brown solonetzic-solonchakous light loamy soils }\end{array}$} \\
\hline A & $0-14$ & C & 10YR6/2 & $\begin{array}{l}\text { SG\& } \\
\text { abk, } \\
\text { f\&m, } \\
1\end{array}$ & SC & SO & 2 & $1, \mathrm{f}$ \\
\hline B1 & $14-28$ & $\mathrm{C}$ & 10YR5/3 & $\overline{a b k \&}$ & $\mathrm{CL}$ & $\mathrm{H}$ & 2 & $1, \mathrm{f}$ \\
\hline
\end{tabular}




\begin{tabular}{|l|l|l|l|l|l|l|l|l|}
\hline & & & & $\begin{array}{l}\text { SbC, } \\
\text { f\&m, } \\
1\end{array}$ & & & & \\
\hline B2 & $28-44$ & U & 10 YR6/4 & $\begin{array}{l}\text { abk\& } \\
\text { SbC, } \\
\text { f\&m, } \\
1\end{array}$ & SCL & H & 3 & 1, vf \\
\hline BC & $44-89$ & G & 2.5 Y 6/4 & $\begin{array}{l}\text { SG\& } \\
\text { abk, } \\
\text { f\&m, } \\
2\end{array}$ & SCL & VH & 3 & 1, vf \\
\hline C1 & $\begin{array}{l}89- \\
115\end{array}$ & G & $2.5 \mathrm{Y} 6 / 2$ & MA & SCL & H & 3 & 0 \\
\hline C2 & $\begin{array}{l}115- \\
163\end{array}$ & U & 2.5 Y 6/2 & MA & SCL & VH & 3 & $1, \mathrm{f}$ \\
\hline
\end{tabular}

aBoundary: $\mathrm{C}=$ clear; $\mathrm{G}=$ gradual; $\mathrm{U}=$ unknown.

bStructure: $\mathrm{MA}=$ massiv; $\mathrm{sbk}=$ subangular blocky; abk=angular blocky; $\mathrm{f}=$ =fine; $\mathrm{m}=$ =medium; $1=$ moderate, $2=$ strong.

cTexture: $\mathrm{L}=$ loam; $\mathrm{SL}=$ sandy loam, $\mathrm{SC}$ - sandy clay loam, $\mathrm{CL}$ - clay loam, $\mathrm{SCL}$ - sandy clay loam.

eConsistence: $\mathrm{SO}=$ soft; $\mathrm{H}=$ hard; $\mathrm{VH}=$ very hard.

fEffervescence: $1=$ slightly; $2=$ strongly; $3=$ violently

gRoots: $0=$ absent; $1=$ few; $\mathrm{f}=$ fine

The mechanical composition of the soil profiles is mainly sandy and sandy loam, clay, clay loam and sandy clay, sandy clay loam. The structures of the soil profiles are not homogeneous. In the fall places of KU-2 and KU-3, in the lower soil horizons $\left(\mathrm{B}_{2}, \mathrm{BC}, \mathrm{C}_{1}\right.$, $\mathrm{C}_{2}$ ), there is an increased carbonate content (roughly boils from $10 \%$ hydrochloric acid) (Table 2).

In soil sections at the fall places (KU-2 and KU-3), the humus content in horizons A and B exceeds the control level (K-1), respectively, by 1.25 and 3.95 times (Table 3). Nutrients in the studied soils are less of control one. It is noted that humus content in illuvial horizons $\mathrm{B}$ is higher than in upper horizons A. At the fall place of the KU-2 in brown solonetzic, the amount of humus $(0.79 \%)$ corresponds to the control parameters in brown saline alkali soils of K-1. This might serve as a sign of the restoration of the fertile soil layer, 20 years after the «Proton» LV first stage falling in 30.12.1998. At the fall place of the KU-3 in brown solonetzic soils, the humus content $(0.20-0.28 \%$ in horizons A and B) are less of control one (K-1), which might be a sign of preservation of the disturbance of soil structure after 17 years after the «Proton» LV first stage falling in 05.09.2000.

Table 3 - Chemical properties of soils

\begin{tabular}{|c|c|c|c|c|c|c|c|c|c|c|c|c|c|}
\hline $\begin{array}{l}\mathrm{H} \\
\text { or } \\
\mathrm{iz}\end{array}$ & Depth & $\begin{array}{l}\text { Cla } \\
\text { y }\end{array}$ & $\begin{array}{l}\mathrm{p} \\
\mathrm{H}\end{array}$ & $\begin{array}{l}\mathrm{Ca} \\
\mathrm{CO}_{3} \\
, \%\end{array}$ & $\begin{array}{l}\mathrm{N} \\
\text { tot. }\end{array}$ & $\begin{array}{l}\mathrm{P}_{2} \mathrm{O} \\
5 \\
\text { tot. }\end{array}$ & $\begin{array}{l}\mathrm{K}_{2} \\
\mathrm{O} \\
\text { tot. }\end{array}$ & $\begin{array}{l}\text { humu } \\
\text { s }\end{array}$ & $\begin{array}{l}\mathrm{C} \\
\mathrm{a}_{\mathrm{e}}\end{array}$ & $\begin{array}{l}M \\
g_{e} \\
x c\end{array}$ & $\begin{array}{l}N \\
a_{e} \\
x c\end{array}$ & $\begin{array}{l}\mathrm{K}_{\mathrm{e}} \\
\mathrm{xc}\end{array}$ & $\begin{array}{l}\mathrm{Na} \\
\text { fro } \\
\mathrm{m}\end{array}$ \\
\hline on & $(\mathrm{cm})$ & $\begin{array}{l}(\mathrm{g} \\
\mathrm{kg}- \\
1)\end{array}$ & $\begin{array}{l}\mathrm{H}_{2} \\
\mathrm{O}\end{array}$ & $\begin{array}{l}\mathrm{g} \\
\mathrm{kg}- \\
1)\end{array}$ & $(\%)$ & & & & & $\mathrm{l}_{+} \mathrm{kg}$ & & & $\begin{array}{l}\text { the } \\
\text { abs } \\
\text { orpt } \\
\text { ion } \\
\text { cap } \\
\text { acit } \\
\text { y, } \%\end{array}$ \\
\hline
\end{tabular}


KU-2. The place where the LV «Proton» first steps fell in 30.12.1998

Solonetz brown small

\begin{tabular}{|c|c|c|c|c|c|c|c|c|c|c|c|c|c|}
\hline A & $0-12$ & 14.0 & $\begin{array}{l}9 . \\
1 \\
\end{array}$ & 0.0 & 0.06 & 0.10 & 16.3 & 0.35 & $\begin{array}{l}4 . \\
00\end{array}$ & $\begin{array}{l}2 . \\
25\end{array}$ & $\begin{array}{l}0 . \\
26\end{array}$ & $\begin{array}{l}0 . \\
61\end{array}$ & 2.88 \\
\hline B & $12-32$ & 35.7 & $\begin{array}{l}9 . \\
0\end{array}$ & 0.0 & 0.08 & 0.92 & 18.4 & 0.79 & $\begin{array}{l}12 \\
.7\end{array}$ & $\begin{array}{l}6 . \\
50\end{array}$ & $\begin{array}{l}0 . \\
35\end{array}$ & $\begin{array}{l}0 . \\
13\end{array}$ & 10.9 \\
\hline $\begin{array}{l}\text { B } \\
\text { C }\end{array}$ & $32-55$ & 31.2 & $\begin{array}{l}8, \\
1\end{array}$ & 0.1 & 0.04 & 0.17 & 20.1 & 0.45 & $\begin{array}{l}12 \\
.5\end{array}$ & $\begin{array}{l}5 . \\
50 \\
\end{array}$ & $\begin{array}{l}0 . \\
40 \\
\end{array}$ & $\begin{array}{l}0 . \\
09\end{array}$ & 2.72 \\
\hline $\mathrm{C}_{1}$ & $55-90$ & 34.9 & $\begin{array}{l}8, \\
0\end{array}$ & 0.8 & 0.02 & 0.01 & 22.0 & 0.11 & $\begin{array}{l}10 \\
.5 \\
\end{array}$ & $\begin{array}{l}4 . \\
8 \\
\end{array}$ & $\begin{array}{l}0 . \\
43 \\
\end{array}$ & $\begin{array}{l}0 . \\
05\end{array}$ & - \\
\hline $\mathrm{C}_{2}$ & $\begin{array}{l}90- \\
185\end{array}$ & 36.1 & $\begin{array}{l}8, \\
4\end{array}$ & 0.8 & - & - & - & - & - & - & - & - & - \\
\hline
\end{tabular}

KU-3. The place where the LV «Proton» first steps fell in 05.09.2000

Brown solonetsous sandy loam soils

\begin{tabular}{|c|c|c|c|c|c|c|c|c|c|c|c|c|c|}
\hline A & $0-14$ & 8.41 & $\begin{array}{l}7 . \\
5\end{array}$ & 0.0 & 0.08 & 0.34 & 18.2 & 0.28 & $\begin{array}{l}6 . \\
00\end{array}$ & $\begin{array}{l}3 . \\
00\end{array}$ & $\begin{array}{l}0 . \\
27\end{array}$ & $\begin{array}{l}0 . \\
26\end{array}$ & 5.89 \\
\hline $\mathrm{B}_{1}$ & $14-28$ & 38.8 & $\begin{array}{l}8 . \\
3\end{array}$ & 0.0 & 0.09 & 0.21 & 20.3 & 0.20 & $\begin{array}{c}20 \\
.0\end{array}$ & $\begin{array}{l}7 . \\
00\end{array}$ & $\begin{array}{l}3 . \\
16\end{array}$ & $\begin{array}{l}0 . \\
05\end{array}$ & 11.9 \\
\hline $\mathrm{B}_{2}$ & $28-44$ & 35.2 & $\begin{array}{l}7 . \\
9\end{array}$ & 0.8 & 0.07 & 0.24 & 21.4 & 0.24 & $\begin{array}{l}18 \\
.0\end{array}$ & $\begin{array}{l}7 . \\
00\end{array}$ & $\begin{array}{l}0 . \\
86\end{array}$ & $\begin{array}{l}0 . \\
14\end{array}$ & 5.33 \\
\hline $\begin{array}{l}\text { B } \\
\text { C }\end{array}$ & $44-89$ & 22.4 & $\begin{array}{l}7 . \\
9\end{array}$ & 0.8 & 0.05 & 0.21 & 22.6 & 0.13 & $\begin{array}{l}15 \\
.8\end{array}$ & $\begin{array}{l}6 . \\
80\end{array}$ & $\begin{array}{l}0 . \\
82\end{array}$ & $\begin{array}{l}0 . \\
12\end{array}$ & - \\
\hline$\overline{\mathrm{C}_{1}}$ & $\begin{array}{l}89- \\
115\end{array}$ & 0.41 & $\begin{array}{l}7 . \\
9\end{array}$ & 0.6 & - & - & - & - & - & - & - & - & - \\
\hline $\mathrm{C}_{2}$ & $\begin{array}{l}115- \\
163\end{array}$ & 7.66 & $\begin{array}{l}7 . \\
8\end{array}$ & 0.8 & - & - & - & - & - & - & - & - & - \\
\hline
\end{tabular}

K-1. Control point with conditionally clean soil at contiguous territory.

Brown solonetzic-solonchakous light loamy soils

\begin{tabular}{|c|c|c|c|c|c|c|c|c|c|c|c|c|c|}
\hline $\mathrm{A}$ & $0-9$ & 14.8 & $\begin{array}{l}9 . \\
1\end{array}$ & 0.66 & 0.07 & 0.10 & 17.2 & 0.35 & $\begin{array}{l}4 . \\
00\end{array}$ & $\begin{array}{l}2 . \\
25\end{array}$ & $\begin{array}{l}0 . \\
26\end{array}$ & $\begin{array}{l}0 . \\
61\end{array}$ & 9.20 \\
\hline $\mathrm{B}_{1}$ & $9-21$ & 43.3 & $\begin{array}{l}8 . \\
5\end{array}$ & 0.66 & 0.09 & 0.92 & 19.1 & 0.79 & $\begin{array}{l}12 \\
.7\end{array}$ & $\begin{array}{l}6 . \\
50\end{array}$ & $\begin{array}{l}0 . \\
35\end{array}$ & $\begin{array}{l}0 . \\
13\end{array}$ & 14.5 \\
\hline $\mathrm{B}_{2}$ & $21-32$ & 33.7 & $\begin{array}{l}7 . \\
9\end{array}$ & 0.66 & $\begin{array}{l}0.09 \\
0\end{array}$ & 0.10 & 21.0 & 0.45 & $\begin{array}{l}12 \\
.5\end{array}$ & $\begin{array}{l}5 . \\
50\end{array}$ & $\begin{array}{l}0 . \\
40\end{array}$ & $\begin{array}{l}0 . \\
09\end{array}$ & 2.58 \\
\hline $\begin{array}{l}\text { B } \\
\text { C }\end{array}$ & $32-77$ & 32.1 & $\begin{array}{l}7 . \\
9\end{array}$ & 0.66 & 0.06 & 0.11 & 23.0 & 0.33 & $\begin{array}{l}12 \\
.0\end{array}$ & $\begin{array}{l}4 . \\
8\end{array}$ & $\begin{array}{l}0 . \\
37\end{array}$ & $\begin{array}{l}0 . \\
08\end{array}$ & - \\
\hline $\mathrm{C}_{1}$ & $77-99$ & 24.5 & $\begin{array}{l}8 . \\
1\end{array}$ & 1.33 & - & - & - & - & - & - & - & - & - \\
\hline $\mathrm{C}_{2}$ & $\begin{array}{l}99- \\
196\end{array}$ & 30.0 & $\begin{array}{l}7 . \\
5\end{array}$ & 0.50 & - & - & - & - & - & - & - & - & - \\
\hline
\end{tabular}

Increased solontzicity was observed in the soil horizons A and B at the fall places in comparison with the control level. The absorption capacity of sodium in the soils of KU-2 and KU-3 is lower than in the control level - 2.88-10.9\% (KU-2), 5.89-11.9\% (KU-3), 9.2- 14.5\% (K-1).

A strong alkaline $\mathrm{pH}$ range was detected in horizons $\mathrm{A}$ and $\mathrm{B}$ of brown solonetz at the fall place of the KU-2 (9.0-9.1) and in control brown saline alkali soil of K-1 (8.5-9.1). In the remaining horizons of KU-2 and K-1, as well as in brown solonetzic soils, an alkaline pH-medium (7.5-8.4) was established at the fall place of the KU-3. Thus, the processes of transformation of technogenic pollution in the $\mathrm{Yu}-2$ soils are provided by an alkaline and strongly alkaline $\mathrm{pH}$ range.

The topsoil horizon A in the sections studied is characterized by a low content of silty fractions (8.4-14.8\%) (Table 3). This gives grounds for the conclusion regarding the light mechanical 
composition of the surface layers of the soil and their reduced sorption capacity. At the same time, UDMN, settling on soil colloids, can migrate deep into the profile, or on its surface, due to soil erosion by water flows and wind [16-17].

In brown solonetzic soils in the fall place of the KU-3, there can be observed a very loose composition of horizon A (bulk density $0.80 \mathrm{~g} / \mathrm{cm}^{3}$, porousness $70 \%$ ) that is similar to the control K-1 (Table 4). In the horizon B, at the fall place of KU-3, an insignificant compaction to loose was revealed (bulk density $1.13 \mathrm{~g} / \mathrm{cm}^{3}$, porousness $59 \%$ ), while in the control it was very loose. In the lower horizons of KU-3, the soil structure becomes denser, bulk of density from $1.10-1.13 \mathrm{~g} / \mathrm{cm}^{3}$, porousness $55-58 \%$ (BC- $\mathrm{C}_{1}$ horizons) to $1.39 \mathrm{~g} / \mathrm{cm}^{3}$ a bulk of density, $48 \%$ porousness $(80-100 \mathrm{~cm}$ in the horizon $\mathrm{C}_{2}$ ).

Table 4 - Physical properties of soils

\begin{tabular}{|c|c|c|c|c|c|}
\hline Horizon & Depth, cm & $\begin{array}{c}\text { Soil } \\
\text { moisture } \\
\text { of, } \%\end{array}$ & $\begin{array}{c}\text { Soil bulk } \\
\text { density } \\
\text { density, g / } \\
\mathrm{cm}^{3}\end{array}$ & $\begin{array}{c}\text { Specific } \\
\text { gravity, } \mathrm{g} / \\
\mathrm{cm}^{3}\end{array}$ & $\begin{array}{l}\text { Porousness, } \\
\quad \%\end{array}$ \\
\hline \multicolumn{6}{|c|}{$\begin{array}{l}\text { KU-3. The place where the LV «Proton» first steps fell in 05.09.2000 } \\
\text { Brown solonetsous sandy loam soils }\end{array}$} \\
\hline $\mathrm{A}$ & $0-10$ & 7.17 & 0.80 & 2.65 & 70 \\
\hline $\mathrm{B}$ & $10-20$ & 8.71 & 1.13 & 2.60 & 58 \\
\hline \multirow[t]{2}{*}{$\mathrm{BC}$} & $20-30$ & 6.80 & 1.13 & 2.60 & 58 \\
\hline & $30-40$ & 10.2 & 1.14 & 2.55 & 57 \\
\hline \multirow[t]{2}{*}{$\mathrm{C}_{1}$} & $40-50$ & 1.59 & 1.14 & 2.55 & 58 \\
\hline & $50-60$ & 2.13 & 1.10 & 2.55 & 58 \\
\hline \multirow[t]{4}{*}{$\mathrm{C}_{2}$} & $60-70$ & 1.47 & 1.10 & 2.55 & 55 \\
\hline & $70-80$ & 2.66 & 1.39 & 2.55 & 55 \\
\hline & $80-90$ & 1.173 & 1.39 & 2.55 & 48 \\
\hline & $90-100$ & 1.86 & 1.39 & 2.55 & 48 \\
\hline \multicolumn{6}{|c|}{$\begin{array}{l}\text { K-1. Control point with conditionally clean soil at contiguous territory } \\
\text { Brown solonetzic-solonchakous light loamy soils }\end{array}$} \\
\hline $\mathrm{A}$ & $0-10$ & 1.04 & 0.85 & 2.65 & 69 \\
\hline $\mathrm{B}$ & $10-20$ & 1.49 & 0.97 & 2.55 & 57 \\
\hline \multirow[t]{2}{*}{$\mathrm{BC}$} & $20-30$ & 1.48 & 1.08 & 2.55 & 59 \\
\hline & $30-40$ & 3.69 & 1.33 & 2.55 & 49 \\
\hline \multirow[t]{2}{*}{$\mathrm{C}_{1}$} & $40-50$ & 3.81 & 1.17 & 2.60 & 54 \\
\hline & $50-60$ & 3.95 & 1.16 & 2.60 & 54 \\
\hline \multirow[t]{4}{*}{$\mathrm{C}_{2}$} & $60-70$ & 4.1 & 1.16 & 2.70 & 54 \\
\hline & $70-80$ & 4.56 & 1.16 & 2.70 & 54 \\
\hline & $80-90$ & 5.02 & 1.07 & 2.70 & 58 \\
\hline & $90-100$ & 5.82 & 1.07 & 2.70 & 58 \\
\hline
\end{tabular}

At the fall place (KU-3), an increased moistening of soil horizons A, B, BC (7.17$10.2 \%$ ) was determined in comparison with the lower $\mathrm{C}_{1}, \mathrm{C}_{2}(1.47-2.66 \%)$, possibly due to natural flow of flood and rainwater. Migrations of technogenic pollution to depths are inhibited by compacted horizons $\mathrm{C}_{1}, \mathrm{C}_{2}$, with increased carbonate content (Table 2). Thus, in the upper, humid horizons of $\mathrm{A}, \mathrm{B}, \mathrm{BC}$ at the fall place of $\mathrm{KU}-3$, one can assume the advantage of the accumulation processes of UDMN, its chemical transformation in the aquatic environment, and microbiological processing into organic matter.

Analysis of the resistance of ground soils of the $\mathrm{Yu}-2$ zone to mechanical stress from the SLV SP falling 
Clay and loamy-clay ground soils, which occupy most of the area under study (77\%), including in the SLV SP falling places in the center and in the south of the $\mathrm{Yu}-2$, are classified according to the scale of the rock hardness, as soft and earthy $(K K=1.0-0.6)$ (the map-scheme is shown in fig. 4). Sandy-loam ground soils in the north and northeast of the $\mathrm{Yu}-2$ are characterized as loose $(\mathrm{KK}=0.5)$. In general, the ground soils, which cover the investigated area of the $\mathrm{Yu}-2$ zone are unstable to mechanical stress during the falling of the first stage of the «Proton» LV fragments.

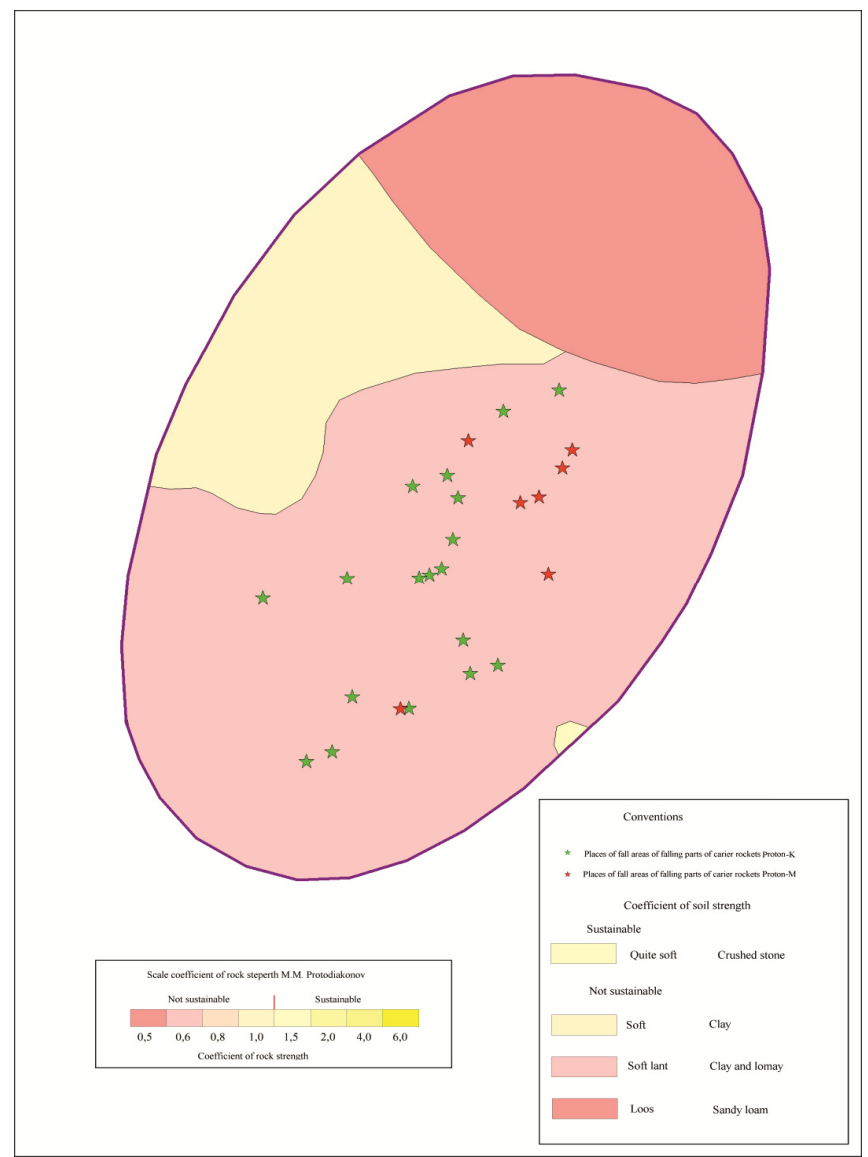

Fig. 4 - Map-scheme of zoning Yu-2 on the criteria of resistance of ground soils to mechanical stres

Conclusions on the results of monitoring studies of soil cover in the $\mathrm{Yu}-2$ zone in 2017

According to the chemical, physical and water-physical properties of the soil (brown soils, solonetz) it has been determined that soil cover at the places of the «Proton» LV first stage falling in the Yu-2 zone demonstrate is resistanced to chemical pollution of UDMN. Surface chemical pollution migration by wind or water flows is ensured in the $\mathrm{Yu}-2$ by an easy mechanical composition and low sorption capacity of the topsoil layer (horizon A). The processes of biological processing of UDMN are assumed in illuvial horizons B, most saturated with humus and moisture. In the same soil layers (horizon B), the physicochemical transformation of UDMN is most probable, due to the high content of exchangeable sodium, against the background of sufficient soil moisture with an alkaline (up to a strongly alkaline) by $\mathrm{pH}$-range. The further migration of chemical pollution to soil depths is impeded by the compacted soil horizons $\mathrm{C}$ (parent rock). 
In the $\mathrm{Yu}-2$ zone, the signs of prolonged accumulation of chemical contamination of UDMN at the SLV SP falling places (up to 10 years or more) are noted with heavy mechanical composition (clay, loams) and low humus content for brown solonetz in complex with solonetzic soils.

According to the physical and water-physical properties the $\mathrm{Yu}-2$ zone soils are unstable to mechanical stress during from the SLV SP falling.

The ground soils (clayey, sandy clay, sandy clay loam) on the scale of the rock hardness are characterized as soft, earthy and loose $(\mathrm{KK}=0.5-1.0)$. In June 2017, disturbances of the topsoil upper fertile layer and compaction of the lower horizons, flat and linear erosion of soils (gullies, depressions, funnels) were found at the places of the «Proton» LV first stage falling.

The character of the regenerative processes of technologically disturbed soils at the places of the «Proton» LV first stage falling in the $\mathrm{Yu}-2$ zone is ambiguous, taking into account the revealed differences in the general soil parameters, namely, in the mechcomposition, water regime, bulk density and porosity as well as by the content of humus and nutrients.

Thus, in the brown solonetz, the signs of restoration of the fertile soil layer were revealed, 20 years after the first stage of the «Proton» LV falling in 30.12.1998. At the same time, traces of anthropogenic disturbance of the soil structure remain in brown solonetzic soils after 17 years falling of the first stage of the «Proton» LV in 05.09.2000.

\section{References.}

1. L.T. Shatrov, D.A. Baranov, B.T. Suymenbaev, Improvement of fire and explosion safety during operation of the exhausted steps of rocket carriers with liquid rocket engines (2016)

2. N.S. Kasymov, Environmental safety of rocket and space activities, 280 (2015)

3. B.T. Suimenbayev, Ekologicheskaya bezopasnost ekspluatatsii raketno-kosmicheskih kompleksov

4. The ecological safety of rocket-space systems operation. Almaty, Giga Treyd Publ., 240 (2009)

5. Ya.T. Shatrov, TsNIIMash Publ., 222 (2010)

6. Dixon John R. Design engineering: inventiveness, analysis and decision making. New York, McGraw-Hill, 1966. (Russ. ed.: Dikson Dzh. Proyektirovaniye sistem: izobretatelstvo, analiz i prinyatiye resheniy. Moscow, Mir Publ., 1969. 440 p.).

7. Zh. Zhubatov, D.S. Alekseeva, E.A. Bekeshev, E.Yu. Stepanova et al., Mater. of the 12th Intern. conf. "Ecology and development of society", 32-36 (2009)

8. Zh. Zhubatov, Environmental safety of the Baikonur Commodore, 430 (2011)

9. Zh. Zhubatov, E.Yu. Stepanova, Mater. of the Intern. scientific and practical conf. "Ecological, Industrial and Energy Security", 459-462 (2017)

10. P.J. Schoene, D.A. Wysok, E.C. Benham, Soil Servey. Field book for describing and sampling soils, version 3.0. USDA Natural Resources Conservation Service, National Soil Survey, Center, Lincoln, NE (2012)

11. G.W. Gee, J.W. Bauder, Particle-size analysis. In Klute A. (ed.) Methods of Soil Analysis, Part 1. Physical and Mineralogical Methods. Agronomy Monograph No. 9 (2ed), American Society of Agronomy/Soil Science Society of America, Madison, WI, 383-411 (1986) 
12. B.H. Sheldrick, C. Wang, Particle Size Distribution. In Carter M.R. (ed.) Soil Sampling and Methods of Analysis, Canadian Society of Soil Science, Lewis Publishers, 499-511 (1993)

13. A.S. Radov, I.V. Pustovoy, A.B. Korol'kov, Agrochemistry practicum (1965)

14. E.V. Arinushkina, Handbook on the Chemical Analysis of Soils (1961)

15. N.S. Kasymov, V.B. Grebenyuk, T.V. Koroleva et al., Behavior of rocket fuel components in soils, waters and plants, 9, 110-120 (1994)

16. Zh. Zhubatov, The system of criteria of ecological sustainability of the territory of the Republic of Kazakhstan to impact of space-rocket activity, 143 (2009) 